\title{
Spray deposition of live cells throughout the electrospinning process produces nanofibrous three-dimensional tissue scaffolds
}

This article was published in the following Dove Press journal:

International Journal of Nanomedicine

25 May 2011

Number of times this article has been viewed

\section{Justin T Seil \\ Thomas J Webster}

Laboratories for Nanomedicine Research, School of Engineering, Brown University, Providence, RI, USA

\begin{abstract}
Compared with traditional in-vitro cell culture materials, three-dimensional nanofibrous scaffolds provide a superior environment for promoting cell functions. Since nanofibrous scaffolds have nanometer pore sizes, cells are unable to penetrate on their own, so must be incorporated into the scaffold during fabrication to ensure proper cell distribution. In this study, biodegradable and cytocompatible poly(DL-lactide-co-glycolide) (PLGA) nanofibers were produced using an electrospinning process. As a model cell line, fibroblasts were periodically sprayed from a pump-action spray bottle onto the developing scaffold. The viability of cells before and after spraying, and also after incorporation into the scaffold, was compared. Results indicated that cell spraying and the scaffold fabrication process did not significantly reduce cell viability. These findings, thus, contribute to the understanding of how to produce more physiological relevant cell-seeded nanofibrous scaffolds, an important element for the future of nanotechnology and tissue engineering.
\end{abstract}

Keywords: nanomaterials, tissue engineering, PLGA, nanotechnology

\section{Introduction}

The desire to produce small-diameter (ie, nanometer) fiber scaffolds for tissue engineering applications is derived, in part, from the resemblance of such scaffolds to naturally occurring extracellular matrix (ECM) proteins. Collagen fibrils, with diameters in the nanometer and submicron range, are a primary component of the ECM. Positive cell responses to scaffolds have been correlated to surface nanotopographies with biomimetic features. While some studies have found that the smallest fibers produced by electrospinning (close to $100 \mathrm{~nm}$ ) are superior, ${ }^{1,2}$ others have concluded that slightly larger, submicron fibers (near $400 \mathrm{~nm}$ ) offer the best performance. ${ }^{3}$ However, in both cases, small-diameter fiber scaffolds provide a significant increase in functional surface area compared with conventional materials with no roughness at the nanoscale. Consequently, more proteins in a more ideal conformation adsorb to nanostructured material surfaces to facilitate enhanced cell attachment. ${ }^{4}$

In addition, compared with cell culture on two-dimensional surfaces, three-dimensional structures allow for a more natural cell attachment and focal adhesion in all directions, a process necessary for proper cell function and survival. The more physiologically relevant cell morphology one can attain on and in three-dimensional scaffolds will provide the best structural cues to regulate cell function. ${ }^{5-7}$ The development of new methods for producing three-dimensional cell scaffolds is, therefore, of great interest. "Organ printing" systems improve two-dimensional cell culture through the deposition of collagen or other ECM-mimicking polymers with cells to build a
Correspondence: Thomas JWebster School of Engineering, Brown University, Providence, RI 02917, USA

Tel + I 4018632677

$\mathrm{Fax}+$ I 40I 8632676

Email thomas_webster@brown.edu 
three-dimensional tissue. ${ }^{8}$ A number of studies have examined such cell responses to those cells simply seeded on top of electrospun scaffolds of significant thickness. ${ }^{1,3,9}$ Although some migration into the scaffold has been reported, the pore size of nanometer fiber scaffolds is generally small enough to prevent substantial migration of cells throughout the scaffold. In an effort to improve cell distribution through such scaffolds, in one study, a parallel electrospinning apparatus drew small droplets of cell suspensions onto the polymer fiber scaffolds to improve cell distribution. ${ }^{10}$

As a continuation of such efforts, the present study investigated the feasibility of producing a cell-seeded, three-dimensional scaffold of fibroblasts and electrospun poly(DL-lactide-co-glycolide) (PLGA) nanofibers. This scaffold was produced via a method of spraying a cell suspension at regular intervals over a continuously produced network of electrospun polymer fibers. In contrast to previous studies in which cells and polymer fibers were deposited simultaneously using a coaxial needle arrangement, ${ }^{11,12}$ here, cells were intermittently sprayed onto a developing scaffold to produce a layered tissue rather than being incorporated into the fibers themselves. Results showed that cells survived the scaffold production process and maintained viability and, thus, should be further studied for nanotechnology-related tissue-engineering applications.

\section{Methods}

\section{Cell culture}

Murine fibroblasts (embryo 3T3; CRL-1658; ATCC, Manassas, VA) were used for cell experiments without further characterization. Fibroblasts were subcultured on tissue culture polystyrene in Dulbecco's modified eagle medium (DMEM) supplemented with 10\% fetal bovine serum (FBS) and $1 \%$ penicillin/streptomycin $(\mathrm{P} / \mathrm{S})$ at $37^{\circ} \mathrm{C}$ in a humidified environment of $5 \% \mathrm{CO}_{2} / 95 \%$ air. Upon reaching $90 \%$ confluency, flasks of fibroblasts (population numbers 3-5) were trypsinized, counted, and used for experimentation.

\section{Cell spray viability}

To investigate potential cell death due to the spraying process, cell viability of a cell suspension was evaluated with and without spraying. After counting and diluting cells to produce a suspension with a density of $2.5 \times 10^{5}$ cells $/ \mathrm{mL}$, the suspension was sprayed into a conical tube with a Bel-Art Spray Pump Bottle (Fisher Scientific, Saint Louis, MO). A $200 \mu \mathrm{L}$ volume of the sprayed cell suspension was then transferred to a well plate and incubated for 1 hour. A comparable, unsprayed volume of the same cell suspensions was also pipetted into a well plate to serve as a control group. After 1 hour, $40 \mu \mathrm{L}$ of an MTS (3-(4,5-dimethylthiazol-2-yl)-5-(3carboxymethoxyphenyl)-2-(4-sulfophenyl)-2H-tetrazolium) reagent (CellTiter $96{ }^{\circledR}$ AQueous One Solution Cell Proliferation Assay, Promega Corporation, Madison, WI) was added to the wells of cell suspension and incubated for 1 hour. The optical density of the formazan produced was read with a spectrophotometer at $490 \mathrm{~nm}$. To further investigate potential cell death due to spraying, an additional cell suspension with the same cell density was sprayed from the collection tube five consecutive times before being sampled and tested for cell viability with the same MTS assay.

\section{Electrospinning setup}

The electrospinning apparatus (previously described in greater detail ${ }^{13}$ ) was set up according to standard operating procedures. PLGA (MW 40,000-70,000, SigmaAldrich, St. Louis, MO) was dissolved in a 1:1 mixture of tetrahydrofuran and dimethylformamide at a concentration of $0.25 \mathrm{~g} / \mathrm{mL}$. The polymer solution was then loaded into a glass syringe with a 20 -gauge metal needle tip. The negative lead of a high-voltage source was connected to the needle tip, while an aluminum foil-covered collector plate was connected to ground. Parameters were adjusted to produce polymer fibers with an approximate diameter of $100 \mathrm{~nm}$ (distance between the needle tip and collector plate $=15 \mathrm{~cm}$, voltage $=18 \mathrm{kV}$, flow rate $=0.5 \mathrm{~mL} / \mathrm{h}$ ). To facilitate removal of the scaffold after the electrospinning process, a glass slide was placed on the collector plate. Polymer nanofibers were produced for 90 minutes with cell suspensions added at 10-minute intervals. For this, cell suspensions were sprayed from a distance of $15 \mathrm{~cm}$ above the collector plate. Polymer nanofiber deposition continued for 10 minutes following the final application of a cell suspension to provide a top layer of polymer nanofibers. After the experiment, the glass slide was carefully excised from the collector plate with a razor blade and transferred to a Petri dish of complete media.

\section{Scanning electron microscopy}

The surface morphology of PLGA fibers was analyzed using a scanning electron microscope (Hitachi 2700, Hitachi HighTechnologies, Berkshire, UK) at magnifications of $6000 \times$ and $30,000 \times$ with an accelerating voltage of $7 \mathrm{kV}$. Images were captured and analyzed with image analysis software (Quartz PCI, Quartz Imaging Corporation, Vancouver, Canada). Polymer nanofiber samples of $1 \mathrm{~cm}^{2}$ were attached to aluminum stubs (Electron Microscopy Sciences, Hatfield, PA) using carbon tape and coated with a $15 \mathrm{~nm}$ layer of $\mathrm{AuPd}$ 
by sputter coating (Emitech K-550, Quorum Technologies, East Sussex, UK) for 2 minutes at $20 \mathrm{~mA}$ from a height of $45 \mathrm{~mm}$.

\section{Scaffold viability}

The viability of cells incorporated into polymer fiber scaffolds was determined using an MTS assay. Following the scaffold production, $1 \mathrm{~cm}^{2}$ pieces of the scaffolds were cut from the collector plate and placed in the well of a 24-well plate containing $500 \mu \mathrm{L}$ of complete DMEM culture media. As a control group, cell suspensions were sprayed eight times from a height of $15 \mathrm{~cm}$ into a $1 \mathrm{~cm}^{2}$ well of a well plate in order to collect approximately the same number of cells that were theoretically deposited on the $1 \mathrm{~cm}^{2}$ sample of scaffold. $500 \mu \mathrm{L}$ of complete DMEM culture media was added to the collected cell suspension. Both the scaffold sample and the collected cell suspension were incubated for 2 hours, along with the polymer nanofiber scaffold that did not contain cells and a well of complete media that did not contain cells. Following incubation, $100 \mu \mathrm{L}$ of the MTS assay solution was added to each well and incubated for 1 hour at $37^{\circ} \mathrm{C}$. A $200 \mu \mathrm{L}$ volume of each resulting solution (with the colored formazan product) was transferred to a 96-well plate, and the optical density was measured with a spectrophotometer at $490 \mathrm{~nm}$. Optical density values were converted to the approximate number of viable cells present.

\section{Statistics}

Numerical data were analyzed for significance using the student's $t$-test. Experiments were performed in triplicate $(\mathrm{N}=3)$. Values are reported as the mean \pm SEM (standard error of the mean). The threshold for significance was set at $P<0.05$.

\section{Results and discussion}

The electrospinning process produced polymer fibers in the nanometer range with an approximate diameter of $100 \mathrm{~nm}$ (Figure 1). This fiber diameter was comparable to dimensions reported in previous literature reports that demonstrated enhanced cellular responses to nanoscale or submicron polymer topographies.

Cell viability assays confirmed that the process of spraying did not kill cells (Figure 2). Although the spraying process subjected cells to increased pressure and shear stress, cell viability was not affected. However, due to the effect that mechanical forces may have on gene expression and cell function, an investigation into the role of these mechanical factors on subsequent cell behavior would

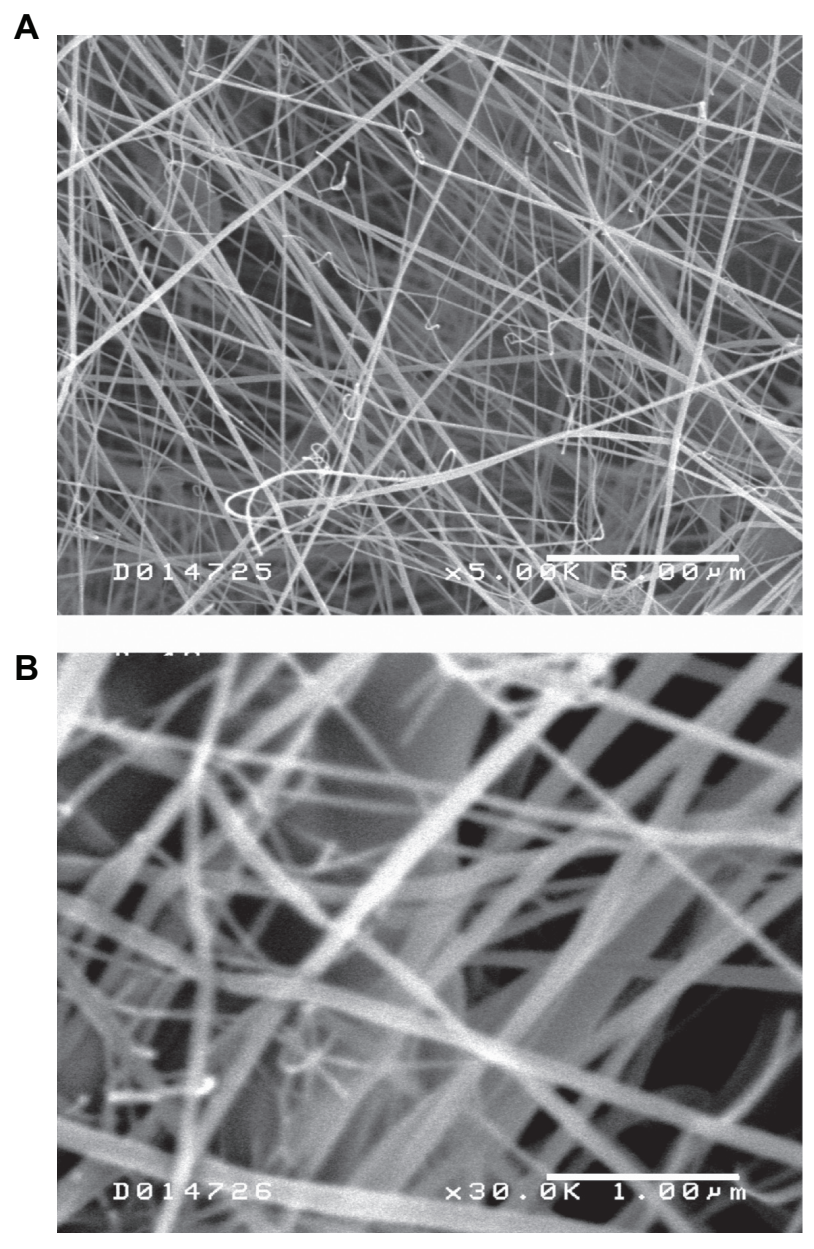

Figure I Scanning electron microscope images of poly(DL-lactide-co-glycolide) nanofibers at 5000 $\times$ magnification (A) and 30,000 $\times$ magnification (B). The polymer fiber diameter was slightly variable with a mean diameter of approximately $100 \mathrm{~nm}$.

need to be conducted to rule out an inhibitory influence of the spraying process. Five consecutive sprays also did not significantly reduce cell populations below that of control groups, further establishing cell survival of the spraying process.

Fibroblasts also survived the scaffold production process. Two hours after the scaffolds were produced, cell viability levels were comparable to that of the approximate number of cells deposited over an area the size of the scaffold sample (Figure 3). This suggests that short-term survival of nearly all incorporated cells is achievable. The porosity of the scaffold was great enough to allow nutrient and cellular waste diffusion; thus, cells will likely be viable for extended periods of time.

This study was built on the premise that to place cells in a more physiological nanofiber scaffold, cells must be incorporated as the scaffold is made. The pore size of small fiber scaffolds is too small to allow for migration of cells 


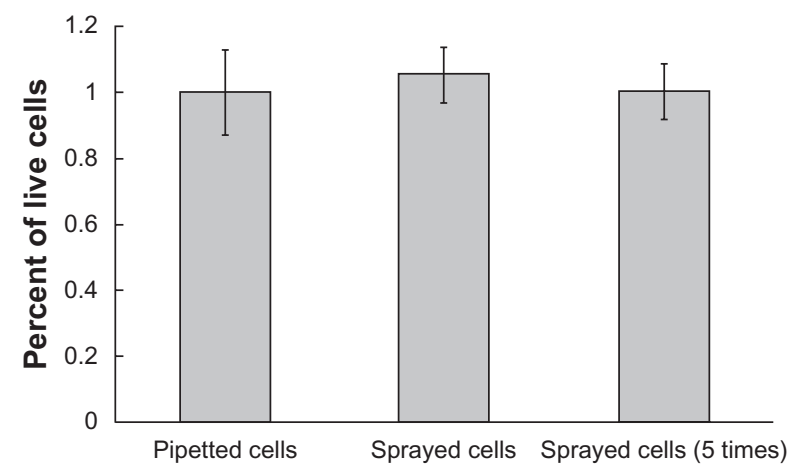

Figure 2 Viability of cells before spraying and after spraying one or five times. No significant difference was found between the viability of cells in these three groups.

after production. Substantial penetration of cells throughout the thickness of the scaffold is very unlikely.

However, one problem associated with incorporating live cells into an electrospun scaffold is the difficulty following aseptic technique. Due to undesirable paths to electrically ground the electrospinning system, a laminar flow hood could not be used here. Consequently, contamination (which would have become evident after extended periods of incubation) may occur during scaffold production and, thus, needs to be further addressed in future studies.

Furthermore, natural tissue has a much more homogenous distribution of cells throughout a tissue, rather than layers of cells between layers of ECM. While a more convenient, automated, and elegant system could be designed to spray smaller volumes of cell suspensions at more frequent intervals, this preliminary study showed promise for such approaches as it maintained cytocompatibility properties after the spraying process.

While other varieties of live cells could be incorporated into such polymer nanofiber scaffolds, $3 \mathrm{~T} 3$ fibroblast precursor cells incorporated into a thin, three-dimensional structure may produce an ideal material for the promotion of wound healing.

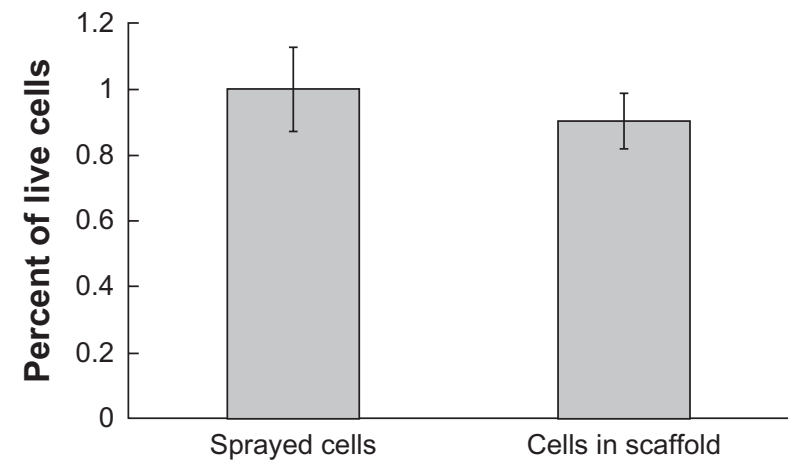

Figure 3 Viability of cells sprayed into polymer nanofiber scaffolds compared with a similar number of cells sprayed into well plates. No significant reduction in cell viability was observed for cells incorporated into scaffolds $(P=0.086)$.
Degradation of the scaffold will take at least several weeks and allow for natural tissue formation. ${ }^{14}$ There is also the potential to use this technology to produce novel cellular co-culture systems in which one type of cell would be encapsulated in the scaffold and a second cell type would be seeded on the outer surface of the scaffold. In this way, the effect of the signaling molecules produced by one cell type could be investigated while physically separating the two cell populations.

\section{Conclusions}

A method of fabricating three-dimensional scaffolds of live cells and polymer nanofibers was developed. In contrast to previous three-dimensional tissue production using electrospinning techniques, the cells were layered throughout the thickness of the scaffold, but not incorporated into individual polymer nanofibers. The production of live-cell scaffolds was confirmed with cell viability assays following fabrication, and, thus, represents a technique that should be further explored for nanotechnology-based tissue engineering applications.

\section{Acknowledgments}

The authors would like to acknowledge the Indo-US Center for Biomaterials for Healthcare for funding and Dr Bikramjit Basu, Dr Dhirendra Katti, Poonam Sharma, and Neha Arya for electrospinning training and project support.

\section{Disclosure}

The authors report no conflicts of interest in this work.

\section{References}

1. Yang F, Murugan R, Wang S, Ramakrishna S. Electrospinning of nano/ micro scale poly(L-lactic acid) aligned fibers and their potential in neural tissue engineering. Biomaterials. 2004;26(15):2603-2610.

2. Matthews JA, Wnek GE, Simpson DG, Bowlin GL. Electrospinning of collagen nanofibers. Biomacromolecules. 2002;3(2):232-238.

3. Chen M, Patra PK, Warner SB, Bhowmick S. Role of fiber diameter in adhesion and proliferation of NIH 3T3 fibroblast on electrospun polycaprolactone scaffolds. Tissue Eng. 2007;13(3):579-587.

4. Webster TJ, Schadler LS, Siegel RW, Bizios R. Mechanisms of enhanced osteoblast adhesion on nanophase alumina involve vitronectin. Tissue Eng. 2001;7(3):291-301.

5. Albrecht DR, Underhill GH, Wassermann TB, Sah RL, Bhatia SN. Probing the role of multicellular organization in three-dimensional microenvironments. Nat Methods. 2006;3(5):369-375.

6. Grinnell F. Fibroblast biology in three-dimensional collagen matrices. Trends Cell Biol. 2003;13(5):264-269.

7. Li W, Danielson KG, Alexander PG, Tuan RS. Biological response of chondrocytes cultured in three-dimensional nanofibrous poly(E-caprolactone) scaffolds. J Biomed Mater Res A. 2003;67A(4): $1105-1114$.

8. Mironov V, Boland T, Trusk T, Forgacs G, Markwald RR. Organ printing: computer-aided jet-based 3D tissue engineering. Trends Biotechnol. 2003;21(4):157-161.

9. Xu C, Inai R, Kotaki M, Ramakrishna S. Electrospun nanofiber fabrication as synthetic extracellular matrix and its potential for vascular tissue engineering. Tissue Eng. 2004;10(7-8):1160-1168. 
10. Stankus JJ, Guan J, Fujimoto K, Wagner WR. Microintegrating smooth muscle cells into a biodegradable, elastomeric fiber matrix. Biomaterials. 2006;27(5):735-744.

11. Townsend-Nicholson A, Jayasinghe SN. Cell electrospinning: a unique biotechnique for encapsulating living organisms for generating active biological microthreads/scaffolds. Biomacromolecules. 2006; 7(12):3364-3369.

12. Sanders EH, Kloefkorn R, Bowlin GL, Simpson DG, Wnek GE. Two-phase electrospinning from a single electrified jet: microencapsulation of aqueous reservoirs in poly(ethylene-co-vinyl acetate) fibers Macromolecules. 2003;36(11):3803-3805.
13. Pham QP, Sharma U, Mikos AG. Electrospinning of polymeric nanofibers for tissue engineering applications: a review. Tissue Eng. 2006; 12(5):1197-1211.

14. Shin HJ, Lee CH, Cho IH, et al. PLGA nanofiber scaffolds for articular cartilage reconstruction: mechanical stability, degradation and cellular response under mechanical stimulation in vitro. J Biomat Sci-Polym E. 2006;17(1-2):103-119.
International Journal of Nanomedicine

\section{Publish your work in this journal}

The International Journal of Nanomedicine is an international, peerreviewed journal focusing on the application of nanotechnology in diagnostics, therapeutics, and drug delivery systems throughout the biomedical field. This journal is indexed on PubMed Central, MedLine, CAS, SciSearch $\AA$, Current Contents ${ } /$ Clinical Medicine,

\section{Dovepress}

Journal Citation Reports/Science Edition, EMBase, Scopus and the Elsevier Bibliographic databases. The manuscript management system is completely online and includes a very quick and fair peer-review system, which is all easy to use. Visit http://www.dovepress.com/ testimonials.php to read real quotes from published authors.

Submit your manuscript here: http://www.dovepress.com/international-journal-of-nanomedicine-journal 